cause. It would be interesting to know how many of the perinatal deaths in the "anoxic" group in Cardiff corresponded to deaths of unknown cause in mature infants and to know the age, parity, height, and social class of the mothers. Higher induction and section rates in these groups most at risk might have resulted in better figures.

Fedrick and Yudkin' reported a reduction in the number of stillbirths in the Oxford area associated with a rising induction rate. The reduction was more apparent in induced than in noninduced births. As they pointed out themselves, however, when the induction rate is low only pregnancies at very great risk are included in an induced group, but as the induction rate rises, more and more relatively normal cases are induced. It is difficult, therefore, to draw firm conclusions about the benefits of induced labour from their method of analysing their data. Possibly the optimum induction rate will vary from area to area depending on the characteristics of the populations. By detailed analysis of our population and classification of the causes of our perinatal deaths, we were able to show where greatest improvement could be made, and it would be valuable to compare our results with those from other centres. Our present findings strongly suggest that increased use of induction of labour has contributed to a reduction in perinatal mortality.

\section{References}

1 Walker, J, Fournal of Obstetrics and Gynaecology of the British Empire, 1954, $61,162$.

${ }^{2}$ Butler, N R, and Bonham, D G, Perinatal Mortality. Edinburgh, Livingstone, 1963.

3 Racker, D, Burgess, G H, and Manly, G, Lancet, 1953, 2, 953.

4 Theobald, G W, Lancet, 1959, 1, 59.

5 Baird, D, British Medical fournal, 1976, 1, 896.

6 Chalmers, I, et al, British Medical fournal, 1976, 1, 735.

7 Baird, D, Walker, J, and Thomson, A M, Fournal of Obstetrics and Gynaecology of the British Empire, 1954, 61, 433

${ }^{8}$ McIlwaine, G M, et al, Health Bulletin, 1974, 32, 1031.

${ }^{9}$ Fedrick, J, and Yudkin, P, British Medical fournal, 1976, 1, 738.

(Accepted 7 December 1976)

\title{
Congestive cardiomyopathy in uraemic patients on long term haemodialysis
}

\author{
TILMAN DRÜEKE, CLAUDE LE PAILLEUR, BRUNO MEILHAC, CONSTANTIN KOUTOUDIS, \\ JOHANNA ZINGRAFF, JEAN DI MATTEO, JEAN CROSNIER
}

British Medical fournal, 1977, 1, 350-353

\section{Summary}

Five uraemic patients who developed progressive cardiac failure with clinical evidence of congestive cardiomyopathy at the start or during haemodialysis treatment were studied. The diagnosis of cardiomyopathy, for which there was no apparent cause, was confirmed by angiocardiographic and haemodynamic studies. These showed a significant increase in left ventricular enddiastolic volume over normal values obtained in 12 patients without uraemia. The mean velocity of myocardial fibre shortening was significantly decreased, as was the index of normalised rigidity. Three of the five patients presented the complete picture of the disease. The other two also had considerable ventricular dilatation and a decreased index of normalised rigidity but normal ejection fraction and only moderately decreased myocardial contractility indices. This suggests that there may be primary involvement of normalised heart muscle rigidity followed by secondary changes in myocardial contractility in uraemic patients with congestive cardiomyopathy.

\footnotetext{
Départements de Thérapeutique Néphrologique and Clinique Cardiologique, Hôpital Necker, Université René Descartes, Paris TILMAN DRÜEKE, MD, physician CLAUDE LE PAILLEUR, MD, physician BRUNO MEILHAC, MD, physician CONSTANTIN KOUTOUDIS, MD, physician JOHANNA ZINGRAFF, MD, chargé de recherche INSERM JEAN DI MATTEO, MD, professor of cardiology JEAN CROSNIER, MD, professor of nephrology
}

\section{Introduction}

Cardiac failure remains one of the most important contributory causes of death in patients undergoing maintenance haemodialysis. ${ }^{12}$ Various factors are implicated in the pathogenesis of heart failure during chronic renal insufficiency-for example, coronary artery disease and hypertension, ${ }^{1}$ pericarditis, hypokalaemia or hyperkalaemia, disorders of calcium metabolism, and possibly anaemia, acidosis, and overhydration with hypervolaemia. $^{3}{ }^{4}$ The question remains whether a specifically "uraemic" cardiomyopathy, due to the retention of normally excreted or metabolised substances, may also be implicated. ${ }^{5}$.

In $1944 \mathrm{Raab}^{7}$ suggested that cardiotoxic substances may exist in the blood and heart muscle in uraemia, and recent experimental evidence has supported the suggestion that uraemia may have a direct effect on myocardial function. During acute renal failure in rats Nivatpumin et $a l^{8}$ observed increased contractility in the myocardium, whereas Riecker et $a l^{4}$ suggested that the contractile state of the acutely uraemic heart was diminished after adrenergic stimulation in the guineapig in vivo. In experimental chronic renal failure Hennemann et $a l^{9}$ reported an increased isometric contraction force of isolated rat atria but a decreased myocardial ${ }^{45} \mathrm{Ca}$ uptake after stimulation with the beta-adrenergic agonist, isoproterenol. Scheuer et $a l^{10}$ provided indirect evidence that uraemic serum had a net depressant effect on myocardial performance in chronically uraemic rats in vivo. They also demonstrated depressed cardiac function when normal rat hearts were perfused with mixtures of urea, creatinine, methyl guanidine, and guanidinosuccinic acid. ${ }^{11}$

In 1967 Bailey et al $^{12}$ described five patients with terminal renal insufficiency who developed severe heart failure that was reversed after intensive haemodialysis. Hypertension and anaemia seemed unlikely major causes of cardiac failure in these patients, and the authors suggested that uraemic "toxins" might be implicated. Recently Scheer et $a l^{13}$ and Rodger et al ${ }^{14}$ presented evidence that cardiomyopathy of unknown cause occurs 
in uraemic patients who are undergoing intermittent haemodialysis. We performed ventriculographic and haemodynamic studies on patients undergoing maintenance haemodialysis who developed chronic heart failure and cardiomegaly of obscure origin and who presented symptoms and signs compatible with the diagnosis of congestive cardiomyopathy. ${ }^{15-17}$

\section{Patients and methods}

Cardiomegaly and heart failure are common complications of endstage renal failure. In most cases they are reversible by haemodialysis. Out of a series of 450 patients on maintenance haemodialysis, however, we saw a few with signs and symptoms of congestive heart failure that developed either during terminal renal failure that remained unchanged by haemodialysis or months after starting haemodialysis. We studied five patients with clinical signs and symptoms ${ }^{15-17}$ of congestive cardiomyopathy who had no evidence of coronary heart disease, endocarditis, pericardial effusion, chronic overload state due to insufficient dialysis, severe anaemia, chronic electrolyte disturbances, or a history of acute myocarditis or infiltrative disease. Typical clinical signs were dyspnoea, chest pain, jugular vein distension, and, especially, a protodiastolic gallop. Their cardiopathy did not respond to intensive dialysis treatment, including major fluid depletion.

The clinical data and dialysis schedule of the five patients are summarised in table I. Haemodialysis was performed using a multilayer plate kidney (RP5) in four cases and a coil kidney (Travenol UF 100 ) in one (case 2). The haemodialysis schedules were similar to those of all the patients in our centre. Fistula flow rates were not measured since there is no precise way of determining external flow. But dialysis blood flow measured during a dialysis session ranged from 110 to $260 \mathrm{ml} / \mathrm{min}$ (ultrasonic flow meter). The fistula providing the lowest flow clotted during the patient's stay in hospital. The low values were probably related to the poor haemodynamic state of the patients. Interdialysis weight changes were no different from those observed in the other patients in the centre.

Cardiological data on the five patients are shown in table II. One patient (case 2) had mild arterial hypertension, but the others were normotensive or had persistent hypotension and no history of longstanding arterial hypertension. Cardiomegaly was already present in one patient (case 5) when she started haemodialysis, but it developed months after the start of haemodialysis in the other four. Only one patient (case 1) had evidence of advanced hyperparathyroidism and soft tissue calcification. Three patients had electrical evidence of uraemic polyneuritis when they were studied but only one of them had clinical signs and symptoms of polyneuropathy. Their diet contained $1 \mathrm{~g}$ protein/kg body weight/day or more, and none had signs of malnutrition before or at the onset of cardiomegaly. None of the patients received cobalt or ingested alcohol chronically. Plasma bicarbonate concentrations did not fall after dialysis in any patient, which suggested that none of them suffered from intradialysis acetate intoxication. ${ }^{18}$ Four of the patients survived. The fifth (case 1) died in another hospital from massive gastrointestinal bleeding due to right heart failure, but no necropsy was performed.

\section{INVESTIGATIONS}

All patients underwent routine clinical examination every one to two weeks and routine electrocardiographic (ECG) and chest $x$-ray examination every three months, or more often if indicated. The patients also had their blood volume, plasma volume, erythrocyte volume, and cardiac index (radioisotope dilution method) measured. Plasma potassium, sodium, and calcium concentrations were measured several hours before cardiac investigation, and the values were all normal.

Ventriculography and haemodynamic studies-Each patient underwent left cardiac catheterisation according to the method described by Seldinger. Left ventricular pressures were recorded by fluid-filled catheter, and left ventricular cineangiography was performed using the oblique right anterior projection (French Cook Catheter No $6.7 \mathrm{~F}$ ). Coronary arteriography completed the study in two patients (cases 3 and 4). In a third (case 5) coronary angiography was interrupted because of transient cardiac arrest at the moment of coronary catheterisation. Left ventricular volumes were calculated according to Greene's method. ${ }^{19}$ The ratio of stroke volume to end-diastolic volume (LVEDV) calculated angiographically represents the ejection fraction (EF). Contractility indices were calculated during the ventricular ejection period by measuring the equatorial diameter from frame to frame, thereby determining the maximum and mean velocity of myocardial fibre shortening (VCF). ${ }^{20} 21$ Indices of normalised rigidity $(k=d P / d V . P)$ and of instantaneous end-diastolic compliance $((\mathrm{dV} / \mathrm{dP}) \mathrm{ED}=1 / \mathrm{k} . \mathrm{LVEDP})$ were calculated by the method of Gaasch $^{22}$ using the simplified diastolic pressure-volume relation $\mathbf{P}=0.43 \mathrm{e}^{\mathrm{kv}}$ and the values of left ventricular end-diastolic volume and pressure (LVEDP). ${ }^{21}{ }^{22}$ In man this simplified single co-ordinate method provides compliance and rigidity values similar to those obtained with the multiple co-ordinate method. ${ }^{23}$ The index of normalised rigidity $(k)$ was independent from the changes of ventricular filling because it was the coefficient of the diastolic pressurevolume exponential $\left(P=0.43 \mathrm{e}^{\mathrm{kv}}\right)$. Conversely, the index of enddiastolic compliance ((dV/dP)ED) depended on instantaneous ventricular filling, and was represented by the inverse value of the slope of the tangent of the diastolic pressure-volume exponential curve. Myocardial thickness was determined in the equatorial plan at the superior part of the left ventricle.

The five patients studied were compared with 12 controls, who included eight patients suffering from thoracic pain but with normal coronary arteriograms and ventriculograms, one with paracardiac tumour, one with cured pericardial effusion, one with unconfirmed suspicion of aortic dissection, and one with functional systolic murmur.

\begin{tabular}{|c|c|c|c|c|c|c|c|c|c|}
\hline $\begin{array}{l}\text { Case } \\
\text { No }\end{array}$ & Sex & $\begin{array}{c}\text { Age** } \\
\text { (years) }\end{array}$ & $\underset{\text { weight* }}{\text { Body }}$ & Type of nephropathy & Nephric state* & $\begin{array}{l}\text { Time on } \\
\text { dialysis } \\
\text { (months) }\end{array}$ & \begin{tabular}{|c|} 
Dialysist \\
schedule \\
(per week; \\
dialysis \\
membrane $1 \mathbf{m}^{2}$ )
\end{tabular} & $\begin{array}{c}\text { Mean } \\
\text { interdialysis } \\
\text { body weight } \\
\text { change } \\
(\mathbf{k g})\end{array}$ & $\begin{array}{c}\text { Motor nerve } \\
\text { conduction } \\
\text { velocity in } \\
\text { peroneal nerve } \\
(\mathrm{m} / \mathrm{s})\end{array}$ \\
\hline $\begin{array}{l}1 \\
2 \\
3 \\
4 \\
5\end{array}$ & $\begin{array}{l}M \\
M \\
M \\
M \\
\mathbf{F}\end{array}$ & $\begin{array}{l}50 \\
38 \\
45 \\
21 \\
30\end{array}$ & $\begin{array}{l}54 \\
59 \\
47 \\
54 \\
45\end{array}$ & $\begin{array}{l}\text { Polycystic disease } \\
\text { Chronic glomerulonephritis } \\
\text { Chronic glomerulonephritis } \\
\text { Chronic glomerulonephritis } \\
\text { Chronic pyelonephritis }\end{array}$ & $\begin{array}{l}\text { Right nephrectomy } \\
\text { Two kidneys } \\
\text { Two kidneys } \\
\text { Right nephrectomy } \\
\text { Right nephrectomy }\end{array}$ & $\begin{array}{r}45 \\
42 \\
14 \\
62 \\
7\end{array}$ & $\begin{array}{l}3 \times 6 \mathrm{~h} \\
3 \times 7 \mathrm{~h} \\
3 \times 6 \mathrm{~h} \\
3 \times 5 \mathrm{~h} \\
2 \times 6 \mathrm{~h}\end{array}$ & $\begin{array}{l}2 \cdot 2 \\
2.3 \\
1.4 \\
2 \cdot 0 \\
0.9\end{array}$ & $\begin{array}{l}37 \\
30 \\
34 \\
41 \\
49\end{array}$ \\
\hline
\end{tabular}

*At time of study. †During year preceding haemodynamic investigation. †During month preceding haemodynamic investigation.

TABLE II-Cardiological data

\begin{tabular}{|c|c|c|c|c|c|c|c|}
\hline $\begin{array}{l}\text { Case } \\
\text { No }\end{array}$ & $\begin{array}{c}\text { Blood pressure* } \\
\text { (mm Hg) }\end{array}$ & $\begin{array}{c}\text { Cardiothoracic } \\
\text { ratio }\end{array}$ & ECG* & $\begin{array}{l}\text { Cardiac index } \\
\left(\mathbf{m l} / \mathbf{m i n} / \mathbf{m}^{2}\right) \dagger\end{array}$ & $\underset{(\mathrm{ml}) \dagger}{\text { Total blood volume* }}$ & $\underset{(\mathrm{ml}) \dagger}{\text { Blood erythrocytes* }}$ & $\begin{array}{l}\text { Packed cell } \\
\text { volume (\%) }\end{array}$ \\
\hline $\begin{array}{l}1 \\
2 \\
3 \\
4 \\
5\end{array}$ & $\begin{array}{l}110 / 60 \\
150 / 100 \\
100 / 70 \\
140 / 90 \\
115 / 75\end{array}$ & $\begin{array}{l}0.62 \\
0.60 \\
0.69 \\
0.62 \\
0.61\end{array}$ & $\begin{array}{l}\text { Normal } \\
\text { Right bundle-branch block } \\
\text { Left ventricular hypertrophy } \\
\text { Left ventricular hypertrophy } \\
\text { Anterolateral ischaemia }\end{array}$ & $\begin{array}{c}\text { ND } \\
4684(+51 \%) \\
837(-71 \%) \\
\text { ND } \\
4570(+64 \%)\end{array}$ & $\begin{array}{c}\text { ND } \\
5480(+25 \%) \\
3110(-12 \%) \\
\text { ND } \\
3950(+26 \%)\end{array}$ & $\begin{array}{c}\text { ND } \\
897(-47 \%) \\
1103(-19 \%) \\
\text { ND } \\
790(-31 \%)\end{array}$ & $\begin{array}{l}35 \\
20 \\
41 \\
20 \\
25\end{array}$ \\
\hline
\end{tabular}
*At time of study. †Percentage deviation from patient's theoretical value is also shown. $\$$ Mean value in three months before study.
ND $=$ Not determined. 
TABLE III-Haemodynamic and ventriculographic data

\begin{tabular}{|c|c|c|c|c|c|c|c|c|c|}
\hline Case No & $\begin{array}{c}\text { Heart rate } \\
\text { (beats } / \mathrm{min} \text { ) }\end{array}$ & $\underset{\left(\mathrm{ml} / \mathrm{m}^{2}\right)}{\text { LVEDV }}$ & $\begin{array}{l}\text { Wall thickness } \\
(\mathrm{cm})\end{array}$ & $\begin{array}{l}\text { LVEDP } \\
(\mathrm{mm} \mathrm{Hg})\end{array}$ & $\mathrm{EF}$ & $\left|\begin{array}{l}\text { Mean VCF } \\
\text { (length/sec) }\end{array}\right|$ & $\begin{array}{c}\text { Maximum } \\
\text { VCF } \\
\text { (length/sec) }\end{array}$ & $k=\frac{d P}{d V . P}$ & $\frac{\mathrm{dV}}{\mathrm{dP}} \mathrm{ED}$ \\
\hline $\begin{array}{l}1 \\
2 \\
3 \\
4 \\
5\end{array}$ & $\begin{array}{r}64 \\
98 \\
105 \\
60 \\
96\end{array}$ & $\begin{array}{l}228 \\
138 \\
253 \\
163 \\
170\end{array}$ & $\begin{array}{l}1.0 \\
1.2 \\
0.95 \\
1.4 \\
1.0\end{array}$ & $\begin{array}{l}18 \\
10 \\
30 \\
10 \\
20\end{array}$ & $\begin{array}{l}0.25 \\
0.57 \\
0.23 \\
0.56 \\
0.28\end{array}$ & $\begin{array}{l}0.34 \\
0.64 \\
0.10 \\
0.73 \\
0.43\end{array}$ & $\begin{array}{l}0.54 \\
1.10 \\
0.40 \\
1.44 \\
0.85\end{array}$ & $\begin{array}{l}0.0163 \\
0.0228 \\
0.0167 \\
0.0193 \\
0.0126\end{array}$ & $\begin{array}{l}3.391 \\
4.385 \\
1.986 \\
5 \cdot 180 \\
3.950\end{array}$ \\
\hline$\pm \mathrm{SE}$ of mean & $84 \div 9$ & $190 \pm 21$ & $1.1 \pm 0.08$ & $17 \pm 3 \cdot 7$ & $0.37 \div 0.07$ & $0.44 \div 0.11$ & $0.86 \pm 0.18$ & $0.017: 0.001$ & $3.77 \pm 0.53$ \\
\hline 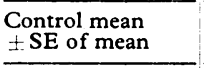 & $88 \pm 4$ & $71 \pm 4$ & $1.0 \pm 0.03$ & $8+0.8$ & $0.61: 0.03$ & $1.25 \dashv 0.09$ & $1 \cdot 85 \pm 0 \cdot 14$ & $0.041 \pm 0.002$ & $3 \cdot 38 \div 0 \cdot 39$ \\
\hline $\begin{array}{l}\mathrm{U} \text { test: } \mathrm{Uxy} \text { or Uyx } \\
\text { (smaller of the } \\
\text { two values) } \\
\end{array}$ & 29 & 0 & 14 & 6 & 10 & 0 & 4 & 0 & 25 \\
\hline$P$ & NS & $<0.01$ & NS & $<0.01$ & $<0.05$ & $<0.01$ & $<0.01$ & $<0.01$ & NS \\
\hline
\end{tabular}

LVEDV $=$ Left ventricular end-diastolic volume. $L V E D P=$ Left ventricular end-diastolic pressure. $E F=E j e c t i o n$ fraction. VCF $=$ Velocity of myocardial fibre shortening. $\mathrm{k}=$ Normalised ventricular rigidity index. $(\mathrm{dV} / \mathrm{dP}) \mathrm{ED}=$ End-diastolic compliance index.

We used the non-parametric U-test of Mann and Whitney ${ }^{24}$ for statistical analysis because of the small number of subjects studied.

\section{Results}

The coronary arteries were normal in the two patients studied by coronary arteriography (cases 3 and 4). No localised dyskinesia or akinesia was observed. The haemodynamic and ventriculographic data of the patients are detailed in table III. The mean heart rate of the uraemic patients was not significantly different from that of the controls. The uraemic patients were characterised by a striking ventricular dilatation, as shown by an increase in left ventricular enddiastolic volume to values greater than any of the control values $(P<0.01)$. Similarly, the normalised ventricular rigidity index was significantly diminished $(P<0.01)$ in all five uraemic patients. Enddiastolic compliance was within normal limits, as was end-diastolic myocardial wall thickness for the group as a whole. In contrast to the homogenous increase in left ventricular end-diastolic volume and decrease in the ventricular rigidity values, the ejection fraction was diminished in only three patients but was nearly normal in the remaining two (cases 2 and 4$)$. The decrease was significant $(P<0.05)$, however, for the group as a whole when compared with controls. Similarly, left ventricular end-diastolic pressure was significantly increased $(P<0.01)$ in the uraemic group as a whole but was within normal limits in cases 2 and 4. Moreover, the contractility indices and the maximum myocardial fibre shortening were decreased $(P<0.01)$ when compared with those of control subjects. The contractility indices in cases 2 and 4 were only moderately decreased when compared with the striking decreases in the other three patients.

\section{Discussion}

Cardiac failure has long been known as a complication of chronic renal insufficiency. ${ }^{3}{ }^{4}$ Heart volume is often augmented, generally because of pericardial or myocardial involvement. Only a few studies of cardiac function have been performed in such patients, ${ }^{25}$ however, and myocardial contractility and compliance have been poorly explored in uraemic patients. Recently Scheer et $a l^{13}$ described seven patients undergoing haemodialysis who had developed chronic heart failure and cardiomegaly of obscure origin. Four had evidence of cardiomyopathy : (a) a diminished ejection fraction and indices of myocardial contractility determined during the isovolumic phase, and $(b)$ a significant increase in end-diastolic pressure. But values of enddiastolic ventricular volume or myocardial compliance were not given. Rodger et al ${ }^{14}$ reached a similar conclusion about the occasional development of congestive cardiomyopathy in patients on dialysis investigated by echocardiography. Using ventriculography and haemodynamic investigations we confirmed our clinical suspicion that some of our patients on haemodialysis had congestive cardiomyopathy.

The incidence of congestive cardiomyopathy in uraemic patients adequately treated by intermittent haemodialysis is not known. Our incidence of $1 \cdot 1^{\circ}$ ( 5 out of 450 ) probably underestimates the real incidence since another seven of our patients showed early evidence of congestive cardiomyopathy but have not yet been investigated by ventriculography and haemodynamic studies. The prevalence of congestive cardiomyopathy in the general population is unknown. Its frequency in a selected population with cardiac disorders has been estimated at $2 \%{ }^{17}$ The incidence of congestive cardiomyopathy in haemodialysed patients is probably much higher than in the non-uraemic population.

Arterial hypertension is unlikely to hnve caused the cardiomyopathy in our patients since four of them had normal or low blood pressures and no history of hypertension. Furthermore, raised blood pressure causes myocardial hypertrophy ${ }^{26}$ and not an increase in ventricular volume, ${ }^{27}$ and we found no change in myocardial thickness but an increase in ventricular volume in all five patients. Coronary heart disease cannot be definitely excluded in three of the five patients since coronary arteriography was performed only in two. Nevertheless, normalised cardiac rigidity is not significantly changed in patients with coronary artery disease in the absence of previous myocardial infarction. ${ }^{21}$

Three of the five patients presented with the complete picture of the disease-that is, considerable ventricular dilatation and myocardial hypokinesia. The remaining two, despite having ventricular dilatation and a decreased index of normalised rigidity, had only a moderate decrease in myocardial contractility and normal ejection fractions. Possibly the cardiomyopathy initially affects normalised heart muscle rigidity, which leads to a primary dilatation of the ventricles. The change of myocardial contractility might be due to the chronic augmentation of systolic wall stress secondary to increased ventricular dimensions.

Studies of cardiac performance during experimental renal failure are scarce ${ }^{8-11}$ and so far inconclusive. Most studies have been performed using the model of either acute renal failure or mild chronic renal failure. The contractile force of rat hearts in vivo was increased during acute failure, and probably decreased during chronic renal failure. ${ }^{10}$ Circulating toxic compounds in the uraemic blood have been incriminated in depression of cardiac contractility. ${ }^{71118}$ The meaning of such results obtained during mild renal failure for endstage renal failure is not clear.

Our results are at variance with the experimental animal data in that the first event in the development of congestive cardiomyopathy in our patients seemed to be diminished normalised rigidity followed by a decrease in contractility. They are further at variance with the observations of Bailey et al, ${ }^{12}$ who described a cardiomyopathy in uraemic patients that was reversed by adequate dialysis. The cardiomyopathy in four of our patients occurred after they had been on haemodialysis for many months and did not improve in spite of intensive haemodialysis. The moderate anaemia in four of our patients might have favoured ventricular dilatation but there is no apparent correlation 
between the degree of severity of anaemia and of ventricular dilatation.

If congestive cardiomyopathy in chronically uraemic patients on dialysis is a syndrome of homogeneous origin and similar evolution in all cases then an intensified search for the factors that may cause it is indicated. In this way the syndrome could be diagnosed at an early stage and treated.

Requests for reprints should be addressed to $\mathrm{Dr} T$ Drüeke, Départements de Thérapeutique Néphrologique, Hôpital Necker, 161 rue de Sèvres, 75730 Paris Cédex 15, France.

\section{References}

${ }^{1}$ Brunner, F P, et al, Proceedings of the European Dialysis and Transplant Association, 1974, 12, 1.

2 Lindner, A, et al, New England fournal of Medicine, 1974, 290, 697.

${ }^{3}$ Bailey, G L, in Cardiovascular Problems, Hemodialysis, Principles and Practice, ed G L Bailey, p 16. New York and London, Academic Press, 1972.

${ }^{4}$ Riecker, G, et al, in Uremia, an International Conference on Pathogenesis, Diagnosis and Therapy, ed R Kluthe, G Berlyne, and B Burton, p 72. Stuttgart, Georg Thieme, 1972.

5 Gueron, M, et al, Nephron, 1975, 15, 2.
6 Prosser, D, and Parsons, V, Nephron, 1975, 15, 4.

7 Raab, W, fournal of Laboratory and Clinical Medicine, 1944, 29, 715.

${ }^{8}$ Nivatpumin, T, et al, American fournal of Physiology, 1975, 229, 501.

9 Hennemann, $\mathrm{H}$, et al, paper presented at VIth International Congress of Nephrology, Florence, Italy, 1975, abstract 555.

10 Scheuer, J, et al, Proceedings of the Society for Experimental Biological Medicine, 1975, 150, 471.

11 Scheuer, J, and Stezoski, S W, fournal of Molecular and Cellular Cardiology, 1973, 5, 287.

12 Bailey, G L, et al, Transactions of the American Society for Artificial Internal Organs, 1967, 13, 263.

13 Scheer, R L, et al, Kidney International, 1975, 8, 419.

14 Rodger, J C, et al, Kidney International, 1976, 9, 380.

15 Goodwin, J F, Lancet, 1970, 1, 731.

${ }_{16}$ Grosgogeat, Y, et al, Revue du Praticien, 1970, 20, 153.

17 Di Mattéo, J, et al, Archives des Maladies du Coeur, 1972, 65, 19.

18 Kirkendol, P L, et al, Kidney International, 1975, 8, 427.

${ }^{10}$ Greene, D G, et al, Circulation, 1967, 35, 61.

20 Karliner, J S, et al, Circulation, 1971, 44, 323.

${ }^{21}$ Le Pailleur, C, et al, Archives des Maladies du Coeur, 1976, 69, 239.

${ }_{22}$ Gaasch, W H, et al, Circulation, 1972, 45, 746.

${ }^{23}$ Gaasch, W H, et al, American fournal of Cardiology, 1975, 36, 193.

24 Schwartz, D, in Méthodes Statistiques à l'Usage des Médecins et des Biologistes. Paris, Flammarion, 1972.

${ }^{25}$ Del Greco, F, et al, Circulation, 1969, 40, 87.

${ }_{26}$ Mason, D T, American fournal of Cardiology, 1973, 32, 437.

27 Grant, C, et al, American fournal of Medicine, 1965, 39, 1969.

(Accepted 7 December 1976)

\title{
CONDENSED REPORT
}

\section{Accidental hypothermia and impaired temperature homoeostasis in the elderly}

\author{
K J COLLINS, CAROLINE DORE, A N EXTON-SMITH, R H FOX, I C MACDONALD, \\ PATRICIA M WOODWARD
}

constrictor pattern of vasomotor response to cold, and a higher incidence of orthostatic hypotension.

\section{Summary}

A longitudinal study of the age-related decline in thermoregulatory capacity was made in 47 elderly people to try to identify those at risk from spontaneous hypothermia. During the winters of 1971-2 and 1975-6 environmental and body temperature profiles were obtained in the home, and thermoregulatory function was investigated by cooling and warming tests. Environmental temperature and socioeconomic conditions had not changed but the body core-shell temperature gradients were smaller in 1976, indicating progressive thermoregulatory impairment. People at risk of developing hypothermia also seem to have low resting peripheral blood flows, a non-

\footnotetext{
MRC Environmental Physiology Unit, London School of Hygiene and Tropical Medicine, London WC1E 7HT

$\mathrm{K} J$ COLLINS, MB, DPHIL, member of scientific staff CAROLINE DORE, BSC, member of scientific staff
Geriatric Department, University College Hospital, London WC1E 6AU

A N EXTON-SMITH, MD, FRCP, professor of geriatric medicine

*MRC Division of Human Physiology, Hampstead, London NW3 6RB R H FOX, DSC, MRCP, member of scientific staff

I C MACDONALD, PHD, member of scientific staff

PATRICIA M WOODWARD, BSC, member of scientific staff

*This division has now been disbanded.
}

\section{Introduction}

Each winter in the British Isles old people die at home as the result of cold. Indeed, accidental hypothermia (deep body temperature below $35^{\circ} \mathrm{C}$ ) is now recognised as one of the natural hazards of old age. The problem is not simply one of unintentional accidental hypothermia resulting from a fall or accident at home and subsequent immobilisation and exposure, nor one entirely associated with concurrent illness ${ }^{12}$; spontaneous hypothermia also occurs among apparently fit elderly people. $^{3}{ }^{4}$

The main objectives of our investigations were to clarify the physiological basis of the ageing process in thermoregulation and to try to identify by physiological means those members of an elderly population sample living at home who seem likely to be at risk of developing hypothermia. We performed cross-sectional and longitudinal studies of a group of elderly volunteers; we obtained temperature profiles in their homes and made subsequent physiological studies in the geriatric research unit at University College Hospital, London, during the winter months (January-March) of 1972 and 1976.

\section{Methods}

We studied 47 elderly people ( 19 men and 28 women) living in the London Borough of Camden. In 1976 their ages ranged from 69 to 90 